\title{
The Impact of Brand Equity on Patients' Purchasing Behaviors in Private Dental Practice in Jeddah, Saudi Arabia
}

\author{
Ala'Eddin Mohammad Khalaf Ahmad ${ }^{1}$, Hussein M. Al-Borie ${ }^{2}$, Eyad Abdulqader Kamal ${ }^{3}$, Fatemah Abdulaziz \\ Abdulfattah $^{4} \&$ Alaa Yasser Abdullah Rhbeini ${ }^{5}$ \\ ${ }^{1}$ Associate Professor of Marketing, Faculty of Economics and Administration, King Abdul-Aziz University, Jeddah, \\ Kingdom of Saudi Arabia \\ ${ }^{2}$ Associate Professor of Health Services Management, Faculty of Economics and Administration, King Abdul-Aziz \\ University, Jeddah, Kingdom of Saudi Arabia \\ ${ }^{3}$ Dentist, Head of Security Forces Polyclinics-Jeddah, Saudi Arabia \\ ${ }^{4}$ Dentist, Master in Health Services Administration, Kingdom of Saudi Arabia \\ ${ }^{5}$ General Dentist, King Abdul-Aziz University, Kingdom of Saudi Arabia \\ Correspondence: Ala'Eddin Mohammad Khalaf Ahmad, Associate Professor of Marketing, Faculty of Economics \\ and Administration, King Abdul-Aziz University, Jeddah, Kingdom of Saudi Arabia. Tel: 966-56-852-7444. E-mail: \\ amahmed1@kau.edu.sa / aladdin.a.h@hotmail.com
}

Received: May 26, 2016

doi:10.5430/jbar.v5n2p41
Accepted: September 6, 2016

Online Published: September 20, 2016

\begin{abstract}
The current research investigates brand equity on patients' purchasing behaviors in private dental practice in Jeddah. This research proposes and tests a four-factor model that influences purchasing behaviors. These factors include the independent variables of brand awareness, brand image, brand loyalty, and perceived quality, while the dependent variable is purchasing behavior. In order to explore this issue, a quantitative method was used in the form of a questionnaire issued in the researched hospitals in Jeddah city in Saudi Arabia. The research targeted a sample of 360 patients, instead of the entire population. A random sample was used to choose the participants in this research. The research retrieved 306 valid questionnaires, which represented a response rate of $85 \%$. The results confirm significant differences in the influence of these factors on purchasing behavior. The research concludes that there are significant influences from brand awareness, brand image, brand loyalty, and perceived quality. The research recommends that medication accessibility and availability needs regularly improved, and purchasing behaviour continuously monitored. It is also recommended that the dental service provider should concentrate on perceived quality by improving their technical equipment, using an expert frontline staff pool to select their employees from, and providing qualified dental services represented by perfect behavior, and a decent-looking and comfortable environment.
\end{abstract}

Keywords: Brand equity, Purchasing behavior, Dental practices, Saudi Arabia

\section{Introduction}

Marketing in healthcare is relatively new, which makes it a topic of considerable value (Corbina, Kelley, \& Schwartz, 2001). Focusing on patient demand directs the healthcare market to become service-oriented (Solayappan \& Jayakrishnan, 2010). Private healthcare services are facing growth of competition, uncertainty of cost, and rapid technological development, resulting in ambiguous patients' purchasing behavior (Duggirala et al., 2008). In fact, brand is a major marketing tool used to guide patients in comparing between different healthcare institutions. It is known that brand combines a name, term, sign, symbol, or design, and is designed to identify the goods or services of one seller or group of sellers, and to mark them out as different from those of competitors (Kotler et al., 2008). Brand can be seen from a marketing or customer perspective as a promise and delivery of an experience, from a staff perspective as the culture and mission, and finally from a business perspective as the security of future earnings (Kumar et al., 2014). The roles of brand in service organizations can be very positive in constructing flexibility against competitors, giving competitive benefits including fruitful augmentations, empowering customers to receive a better picture, comprehending services before purchasing, and finally decreasing apparent financial and social risks in purchasing services (Kim \& Kang, 2008). As the patients' needs and wants are the basis for all actions in 
healthcare organizations, brand building is connected with patients' perception of promised value and supported by significant components, which are awareness, perceived quality, image and loyalty (Solayappan \& Jayakrishnan, 2010). Brand elements enable the patient to map his brain and construct brand equity, which can properly represent the brand and its points of difference from competing brands. Lately, brand equity has gradually defined inpatient-based contexts (Chieng \& Goi, 2011). The brand equity concept was developed since the late 1980s and framed by several researchers, such as Aker, Keller and others. A recent definition, as stated by the American Marketing Association, is "The value of a brand from a consumer perspective and attitudes about positive brand attributes and favorable consequences of brand use" (Chieng \& Goi, 2011). When measured effectively, brand equity is the suitable metric for assessing the long-run effect of marketing decisions. Positive patient-based brand equity can gain more excellent returns, lower expenses, and higher benefits; and it has immediate ramifications for the organization's capability to set higher prices, patients' willingness to pay more, the effectiveness of marketing communications, and the success of brand extensions and licensing opportunities (Jalilvand, Samiei \& Mahdavinia, 2011). There has been some research into brand equity in the service domain, such as banks, hotels and airlines, but limited research has been done on services in the healthcare sector; dentistry in particular. Dental patients in the private sector in Saudi Arabia were chosen to be the focus of this research for several reasons. Private dental patients are considered as the second highest percentage in the dental market. Patients need several visits to the dental clinic for treatment, which varies depending on whether they require pain relief, prevention and cosmetics; patients pay per procedure or by premiums according to the healthcare pricing policy; patients might avoid it because of pain, fear and doubt of either the clinic or the staff. The research problem of the current research is trying to shed light on dental patients and their relations to brands. This makes the healthcare providers need to know answers for such questions as what makes them purchase, and what will attract new patients and retain existing ones. This research investigates the impact of brand equity on patient purchasing behavior in Saudi private dental clinics in Jeddah city.

\section{Literature Review}

\subsection{Brand Equity in Services Industries}

Services branding has become a growing industry, despite such challenging characteristics as inseparability, heterogeneity, intangibility, and perishability. In fact, these characteristics alter the measurement of brand equity between services and physical goods. In services, customers purchase something invisible which cannot be measured directly. This could be considered as a reason for the lack of studies on this subject. Yet, some researchers tried to adopt a consumer-based brand equity for assessing brand equity in services (Kotler, Shalowitz \& Stevens, 2008). To begin with, brand equity has numerous definitions, which have been formulated by several authors. But the most suitable definition for this study is by Aaker (1991), whose definition is "a set of assets associated with the brand [which] include brand loyalty, brand awareness, brand association, and perceived quality". These assets have been examined and checked by academics such as Atilgan et al. (2005) and Pappu et al. (2005). On the other hand, Keller (1993) sees brand equity in terms of brand knowledge, in other words brand awareness and brand image. Lassar et al. (1995), however, see brand equity in terms of five dimensions, which are performance, social image, value, attachment, and trustworthiness (Kim et al., 2003) connected to service brand equity (in hotels) using brand loyalty, brand awareness, perceived quality, and brand image. A further study by Kim et al. (2008) looked at trust, customer satisfaction, relationship commitment, brand loyalty, and brand awareness and identified them as significant in their impact on the branding of healthcare. The literature shows that quality, loyalty, image, association (image) and awareness are the important components of service brand equity (Chahal \& Bala, 2012). Krishnan and Hartline (2001), who tried to find out about brand equity in services in general, evaluated brand equity in services marketing against that for goods. Their research looked into three types of services and one type of tangible good for their research, according to three attributes that goods and services possess; which are search, experience, and credence attributes. Their study showed that brand equity is more important for services than for goods, which is quite a different view from the traditional literature review (Sun, 2004). Mackay (2001) applied existing consumer-based measures of brand equity to a financial services market. His study is meaningful in that it is the first attempt to adopt the measurement of consumer-based brand equity to the services industry. He finds that the measurement is reliable and valid in service marketing, and that the best measurement of brand equity in terms of correlation with market share is brand awareness (Sun, 2004). Therefore, it is hypothesized that:

Brand equity has a positive significant influence on patient purchasing behavior in private dental practice in Jeddah city 


\subsubsection{Brand Awareness}

Brand awareness concerns the strength of a brand in consumers' minds, and is an important component of brand equity. Aaker (1991) defined brand awareness as "the ability of the potential buyer to recognize and recall that brand from [a] certain product category". Brand awareness is composed of brand recall and brand recognition. Brand recall means consumers' ability to see a product category and recall a brand name exactly, and brand recognition is when consumers can identify identify a brand from a brand cue. That is, consumers can tell a brand correctly if they see or hear it. Moreover, Hoeffler and Keller (2002) indicated that brand awareness could be distinguished from depth and width. Depth means how to make consumers remember or identify a brand easily, and width expresses how, when consumers buy a product, they will recall a brand name immediately. If a product owns brand depth and width at the same time, consumers will bring to mind a specific brand when they want to buy a product. That is, the product has higher brand awareness. Moreover, brand name is the most significant element in brand awareness (Chi, Yeh, Chien \& Yang, 2009). Customer-based brand equity is when the customer has great awareness of and familiarity with the brand, and has strong, favorable, and unique brand associations in memory (Jalilvand, Samiei \& Mahdavinia, 2011). Some researchers argued that brand awareness is a process of initiating communication between the customer and the company. In other words, a consumer needs to be familiar with the brand before purchasing. Rossiter et al. (1991) support that brand awareness is an essential concept for purchasing behavior (Irshad , 2012 ). Therefore, it is hypothesized that:

Brand awareness has a positive significant influence on patient purchasing behavior in private dental practice in Jeddah city

\subsubsection{Brand Image}

Brand image plays an important role in differentiating the service from that of its competitors (Shanthi, 2006). Brand image is the consumers' perception of a brand as reflected by the brand associations held in their memory. In simple words, it reflects consumers' perception about a brand based on their experience and knowledge (VanAuken, 2007). For example, a company with a positive corporate image might possess individuality and differentiation which could bring increased awareness, loyalty, and reputation (Heerden \& Puth, 1995) and is ultimately in a position to attract consumers. Further, scholars such as Chen (2009), Bibby (2009), and Wood (2000) have highlighted the positive nature of the relationship between brand equity and image. Two kinds of relationships have been observed in the literature, which are the direct effect that brand image has on brand equity, and the indirect effect on brand equity through mediating variables such as brand loyalty. This relationship suggests that brand image causes brand loyalty, and the degree of brand loyalty determines the value of the brand, that is, brand equity. Academics investigating marketing look at the direct relationship between brand equity and brand image, and the indirect relationship between brand equity and brand image through brand loyalty as the mediating factor (Y.L. \& Lee, 2011). Therefore, it is hypothesized that:

Brand image has a positive significant influence on patient purchasing behavior in private dental practice in Jeddah city

\subsubsection{Brand Loyalty}

Brand loyalty, thought of as the best way to achieve brand equity (Atilgan et al., 2005), is seen as a consumer's attachment to a brand, even when an organization changes the price or other product features (Aaker, 1991). It is a function of behavior (i.e. repeat purchases of the brand) and attitude (i.e. dispositional commitment in terms of a unique value pertaining to the brand) (Chahal \& Bala, 2010). Bloemer et al. (1999) identify loyalty to a service comes from purchase intentions, word of mouth communication, price sensitivity, and complaining behavior. In the healthcare sector, service brand loyalty means loyalty of consumers who continue to choose the services from the same healthcare providers (or provider), who have a positive influence on them. Chahal and Bala (2010) see service brand loyalty in conjunction with positive attitude (attitudinal loyalty) and repeat purchase behavior (behavioral loyalty) of consumers toward the hospital. For instance, satisfied patients prefer the same hospital for treatments, whether the same or different, and may recommend it to friends and family. This is not true for patients who are dissatisfied, and might therefore stop using that hospital (Corbin et al., 2000). In this way, patients who are loyal create a solid basis financially for the future, because even following discharge, they still may be affirmative towards the same healthcare organization through positive word of mouth, donations or other forms of co-operation. Despite its significance, public healthcare organizations do not place enough value on the effect loyal patients can have on their success. In other words, patients' loyalty is necessary for healthcare units to retain patients and survive in the competitive market. From the perspective of service, brand loyalty goes together with purchase intention, word of mouth, price sensitivity and 
complaining behaviors, which are the main components of brand loyalty according to Bloemer et al. (1999), Lassar et al. (1995), and Kim et al. (2003) (Chahal \& Bala, 2012). Therefore, it is hypothesized that:

Brand loyalty has a positive significant influence on patient purchasing behavior in private dental practice in Jeddah city

\subsubsection{Perceived Quality}

Perceived service quality is the patients' overall perception of the quality/superiority of a particular product or service in comparison to other available services or products. Aaker (1991) considered it as an intangible overall feeling about a brand, which can affect market share, price, and profitability. The real test for its success depends on the quality of services provided to consumers. To qualify this test and to contribute to brand equity, hospitals must provide "service plus"; in other words, high-quality professional service as well as top patient care, thus quality services that can delight patients. The result of this is to improve the hospital's brand name and image (Shanthi, 2006). How customers perceive the services received is dependent on several factors: experience, knowledge and competence of hospital personnel, together with their commitment, willingness to serve the customer, reliability, trust, empathy and handling of critical factors (Duggirala, Rajendran \& Anantharaman, 2008). The literature reveals that perceived quality includes phenomena such as assurance, tangibles, empathy, reliability, and responsibility, mainly derived from the works of Parasuraman et al. (1985), Aaker (1991), Sohail (2003), Kim et al. (2003), and Thantry et al. (2006) (Chahal \& Bala, 2012). Therefore, it is hypothesized that:

Perceived quality has a positive significant influence on patient purchasing behavior in private dental practice in Jeddah city.

\subsubsection{Purchasing Behaviors}

Before defining purchasing behaviors, it is rational to start with consumer-patients' behaviors, which are defined by Engel et al. (1986) as "those acts of individuals directly involved in obtaining, using, and disposing of economic goods and services, including the decision processes that precede and determine these acts". Consumer purchasing behavior is the decision-making process, consisting of several stages, which people engage in and their actions which satisfy needs and wants in the marketplace. However, there is not a single behavioral standard. Individual consumers behave differently, based on psychological, environmental and situational factors. Most of these factors are beyond the control of marketers but need to be considered while trying to understand the complex behaviors of the consumers-patients (Lamb, Hair \& McDaniel, 2011). To avoid confusion between purchasing behavior and purchasing intention, the latter is pre-purchase effort that may comprise realization of a need or want, and a quest for and assessment of data about the services and brands that may fulfil it. On the other hand, purchasing behavior is post-purchase actions, which include the evaluation of the use of the purchased item and the reduction of any anxiety, which accompanies the purchase of expensive and rarely-purchased items. Each of these has implications for purchase and repurchase and they are amenable in differing degrees to marketer influence.

\section{Rationale for Research}

The intention is for this research to make an original contribution to knowledge by investigating the impact of brand equity on patients' purchasing behaviors in private dental practice in Jeddah. This research adds to the health services marketing discipline in testing components of brand equity, specifically brand awareness, brand image, perceived quality and brand loyalty within the dental service sector. In fact, this study attempts to contribute to marketing knowledge and health services marketing in particular. It employs a quantitative methodology to explore the relationship between brand equity components and purchasing behavior. Such a contribution will be beneficial both academically and professionally. This study aims to focus academic attention on a neglected domain in the context of this research. In addition, professionally, private dental providers will look at the practical implications of such an effort and the possibility of using the implication of this research in their actual relationships with their stakeholders (patients-consumers).

\section{Objectives of the Research}

The current research objectives are:

1- Identifying the main factors which constitute the brand equity components in dental private clinics in Jeddah province.

2- Determining the impact of brand equity on patient purchasing behavior in dental private clinics in Jeddah province. 


\section{Research Methodology}

\subsection{Research Design}

This research is a descriptive analytical research of the relationships existing between dependent and independent variables, as per the research hypotheses. The research design constructed here is based on the hypotheses formulated. These hypotheses were formulated inductively from the researcher's observation and from the literature. The descriptive part is intended to describe and identify the research factors, which constitute factors influencing patient's decision-making components in dental private sector hospitals in Jeddah (Creswell, 2003). In the analytical part, the research model is tested by looking at the impact of brand equity on patient purchasing behavior in Saudi private sector hospitals, in order to search how far the brand equity components will affect purchasing of these services.

\subsection{The Research Population}

The research population consists of patients who visited private dental divisions at the big private hospitals (more than 150-bed capacity) in the city of Jeddah, Saudi Arabia. The population in this research is defined as all the dental divisions in the private hospitals of Jeddah city. The number of dental clinics included in this research was four private hospitals in Jeddah city. The research population consisted of patients who have visited any private dental clinic in these hospitals in 2015 . The average monthly visit was 8112 . The total of all the dental patients participating in the research survey was 360 , and the responses were 306 as a study sample.

\subsection{Primary Data Collection Methods}

The general research picture was developed using a quantitative method. A questionnaire was used as the primary data collection method. The research questionnaire was designed based on the formats of previous empirical literature (Chahal \& Bala, 2012) (Jalilvand, Samiei \& Mahdavinia, 2011). The questionnaire design was pre-tested and redesigned through personal interviews with managers from different private hospitals undertaking the pilot study work (Aker et al., 2001). The features of the components of brand equity and purchasing behavior in the questionnaire are: perceived quality including staff behavior, assurance and tangibles. Brand loyalty includes attitude and behavior. Brand image includes staff behavior, brand image, assurance, attitudinal loyalty tangibles, and behavioral loyalty. Brand awareness includes recognition and familiarity. Finally, purchasing behavior includes preference, revisits and recommendation to others. The questionnaire was translated from English to Arabic and retranslated to English again to prove validity of the Arabic version, then allocated in two languages, Arabic and English, depending on the participant's choice. Marketing personnel handed out the questionnaire regularly until the target sample size was reached. It included the name of the hospital known to respondents, and their readiness to give relevant information on the hospital (open-ended question) was also used. Questions on the patient's length of association with the hospital (multiple choice), whether they used the hospital's services last time (yes or no), type of treatment undergone, and demographic profile, were also included. The factors influencing brand equity were measured on a five-point Likert-scale ranging from 5 (strongly agree) to 1 (strongly disagree). 


\section{Analytical Approach}

\subsection{Results}

Table 1. Frequency and Percentage for Demographic Information

\begin{tabular}{|c|c|c|c|c|}
\hline \multicolumn{2}{|l|}{ Demographic items } & \multirow{2}{*}{$\begin{array}{l}\text { Total } \\
\mathbf{N} \\
306\end{array}$} & \multirow{2}{*}{$\begin{array}{l}\begin{array}{l}\text { Count } \\
\mathbf{N}\end{array} \\
189\end{array}$} & \multirow{2}{*}{$\begin{array}{l}\% \\
61.8 \\
\end{array}$} \\
\hline Gender & Male & & & \\
\hline & Female & & 117 & 38.2 \\
\hline \multirow[t]{2}{*}{ Nationality } & Saudi & \multirow[t]{2}{*}{306} & 261 & 85.3 \\
\hline & Non-Saudi & & 45 & 14.7 \\
\hline \multirow[t]{3}{*}{ Age } & 20-35 years & \multirow[t]{3}{*}{306} & 189 & 61.8 \\
\hline & $36-50$ years & & 108 & 35.3 \\
\hline & Above 50 years & & 9 & 2.9 \\
\hline \multirow[t]{4}{*}{ Monthly income } & Below 5000 & \multirow[t]{4}{*}{306} & 153 & 50.0 \\
\hline & $5001-10000$ & & 54 & 17.6 \\
\hline & $10001-15000$ & & 9 & 2.9 \\
\hline & Above 15000 & & 90 & 29.4 \\
\hline \multirow[t]{3}{*}{ Education } & Matriculate & \multirow[t]{3}{*}{306} & 54 & 17.6 \\
\hline & Graduate & & 153 & 50.0 \\
\hline & Postgraduate & & 99 & 32.4 \\
\hline \multirow{2}{*}{$\begin{array}{l}\text { Do you come to this hospital for dental } \\
\text { services only? }\end{array}$} & Yes & \multirow[t]{2}{*}{306} & 171 & 55.9 \\
\hline & No & & 135 & 44.1 \\
\hline \multirow[t]{2}{*}{ Do you have medical health insurance? } & Yes & \multirow[t]{2}{*}{306} & 180 & 58.8 \\
\hline & No & & 126 & 41.2 \\
\hline
\end{tabular}

Table 1 shows that there was a total of 306 samples. $61.8 \%$ are males and $38.2 \%$ are females; $85.3 \%$ are Saudi and $14.7 \%$ non-Saudi. Among the 306 samples, $61.8 \%$ are $20-35$ years old, $35.3 \%$ are $36-50$ years old and $2.9 \%$ are above 50 years old. As to their monthly income, $50.0 \%$ are receiving below $5000,29.4 \%$ have above $15000,17.6 \%$ have 5001-10000 and 2.9\% are receiving 10001-15000. As to their level of education, 50.0\% are graduates, $32.4 \%$ had postgraduate education and $17.6 \%$ had matriculate level of education. The samples also asked if they only go to the hospital for dental services, to which $55.9 \%$ said yes while $44.1 \%$ said no. Lastly, they asked if they have medical health insurance, and $58.8 \%$ said yes, while $41.2 \%$ said they do not have. 
Table 2. Study variables (gender-nationality-age)

\begin{tabular}{|c|c|c|c|c|c|c|c|}
\hline Domains & & Total & $\begin{array}{l}\text { Perceived } \\
\text { quality }\end{array}$ & $\begin{array}{l}\text { Brand } \\
\text { loyalty }\end{array}$ & $\begin{array}{l}\text { Brand } \\
\text { image }\end{array}$ & $\begin{array}{l}\text { Brand } \\
\text { awareness }\end{array}$ & $\begin{array}{l}\text { Purchase } \\
\text { behavior }\end{array}$ \\
\hline Total & & $306(100.0)$ & $69.18 \pm 13.3$ & $37.65 \pm 8.0$ & $22.82 \pm 5.4$ & $17.97 \pm 4.3$ & $12.03 \pm 3.2$ \\
\hline \multirow[t]{3}{*}{ Gender } & Male & $189(61.8)$ & $71.10 \pm 12.0$ & $39.62 \pm 6.8$ & $23.95 \pm 5.0$ & $19.38 \pm 3.1$ & $12.90 \pm 2.4$ \\
\hline & Female & $117(38.2)$ & $66.08 \pm 14.7$ & $34.46 \pm 8.7$ & $21.00 \pm 5.6$ & $15.69 \pm 4.8$ & $10.62 \pm 3.7$ \\
\hline & p-value & N/A & $0.002^{\mathrm{b}}$ & $<0.001^{\mathrm{b}}$ & $<0.001^{\mathrm{a}}$ & $<0.001^{\mathrm{b}}$ & $<0.001^{\mathrm{b}}$ \\
\hline \multirow[t]{3}{*}{ Nationality } & Saudi & $261(85.3)$ & $69.28 \pm 13.5$ & $37.97 \pm 7.6$ & $23.03 \pm 5.2$ & $17.97 \pm 4.0$ & $12.41 \pm 2.8$ \\
\hline & Non-Saudi & $45(14.7)$ & $68.60 \pm 12.3$ & $35.80 \pm 10.0$ & $21.60 \pm 6.7$ & $18.00 \pm 5.6$ & $9.80 \pm 4.2$ \\
\hline & p-value & N/A & 0.754 & 0.17 & 0.175 & 0.969 & $<0.001^{b}$ \\
\hline \multirow[t]{4}{*}{ Age } & $\begin{array}{l}20-35 \\
\text { years }\end{array}$ & $189(61.8)$ & $67.24 \pm 13.9$ & $36.62 \pm 7.8$ & $22.00 \pm 5.5$ & $17.62 \pm 4.8$ & $11.62 \pm 3.5$ \\
\hline & $\begin{array}{l}36-50 \\
\text { years }\end{array}$ & $108(35.3)$ & $74.58 \pm 9.0$ & $41.08 \pm 5.3$ & $24.58 \pm 5.0$ & $18.92 \pm 2.9$ & $13.25 \pm 1.6$ \\
\hline & $\begin{array}{l}\text { Above } 50 \\
\text { years }\end{array}$ & $9(2.9)$ & $45.00 \pm 0.0$ & $18.00 \pm 0.0$ & $19.00 \pm 0.0$ & $14.00 \pm 0.0$ & $6.00 \pm 0.0$ \\
\hline & p-value & N/A & $<0.001^{\mathrm{c}}$ & $<0.001^{\mathrm{c}}$ & $<0.001^{\mathrm{c}}$ & $0.001^{\mathrm{c}}$ & $<0.001^{\mathrm{c}}$ \\
\hline
\end{tabular}

a-significant using Independent $t$-test @ <0.05 level

b-significant using Welch'st-test @ <0.05 level

c-significant using One-Way ANOVA test @ <0.05 level

Table 3. Study variables (monthly income-educational level)

\begin{tabular}{llllllll}
\hline Domains & & Total & $\begin{array}{l}\text { Perceived } \\
\text { quality }\end{array}$ & $\begin{array}{l}\text { Brand } \\
\text { loyalty }\end{array}$ & $\begin{array}{l}\text { Brand } \\
\text { image }\end{array}$ & $\begin{array}{l}\text { Brand } \\
\text { awareness }\end{array}$ & $\begin{array}{l}\text { Purchase } \\
\text { behavior }\end{array}$ \\
\hline Total & & $306(100.0)$ & $69.18 \pm 13.3$ & $37.65 \pm 8.0$ & $22.82 \pm 5.4$ & $17.97 \pm 4.3$ & $12.03 \pm 3.2$ \\
\hline $\begin{array}{l}\text { Monthly } \\
\text { income }\end{array}$ & Below 5000 & $153(50.0)$ & $66.00 \pm 15.3$ & $35.71 \pm 8.7$ & $21.35 \pm 5.7$ & $17.12 \pm 5.3$ & $11.65 \pm 3.8$ \\
\cline { 2 - 8 } & $5001-10000$ & $54(17.6)$ & $69.83 \pm 6.8$ & $39.67 \pm 4.4$ & $22.33 \pm 5.8$ & $18.33 \pm 3.4$ & $11.50 \pm 1.9$ \\
\cline { 2 - 8 } & $10001-15000$ & $9(2.9)$ & $76.00 \pm 0.0$ & $37.00 \pm 0.0$ & $23.00 \pm 0.0$ & $17.00 \pm 0.0$ & $12.00 \pm 0.0$ \\
\cline { 2 - 8 } & Above 15000 & $90(29.4)$ & $73.50 \pm 11.7$ & $39.80 \pm 8.0$ & $25.60 \pm 3.8$ & $19.30 \pm 2.2$ & $13.00 \pm 2.5$ \\
\cline { 2 - 8 } $\begin{array}{l}\text { Educational } \\
\text { level }\end{array}$ & p-value & N/A & $<0.001^{\mathrm{c}}$ & $<0.001^{\mathrm{c}}$ & $<0.001^{\mathrm{c}}$ & $0.001^{\mathrm{c}}$ & $0.006^{\mathrm{c}}$ \\
\cline { 2 - 8 } & Graduate & $153(50.0)$ & $67.65 \pm 12.7$ & $37.29 \pm 6.2$ & $22.41 \pm 5.1$ & $17.12 \pm 4.4$ & $11.82 \pm 2.7$ \\
\cline { 2 - 8 } & Postgraduate & $99(32.4)$ & $69.91 \pm 15.4$ & $38.00 \pm 9.3$ & $24.27 \pm 5.5$ & $18.45 \pm 3.0$ & $12.18 \pm 3.1$ \\
\cline { 2 - 8 } & p-value & N/A & 0.08 & 0.744 & $0.002^{\mathrm{c}}$ & $0.001^{\mathrm{c}}$ & 0.506
\end{tabular}

c-significant using One-Way ANOVA test @ < 0.05 level

Tables 3 and 4 tested the relationship of all variables relative to the demographics. Specifically, this study is testing whether the perception of the study sample differs with respect to gender, nationality, age, monthly income and educational level. 
Table 4. Significant results in a post-hoc analysis after a significant result from One Way ANOVA test between all variables and age

\begin{tabular}{|c|c|c|c|c|c|c|c|}
\hline \multicolumn{8}{|c|}{ Multiple comparisons } \\
\hline \multirow{2}{*}{$\begin{array}{l}\text { Dependent } \\
\text { variable }\end{array}$} & \multirow[t]{2}{*}{ I } & \multirow[t]{2}{*}{$\mathbf{J}$} & \multirow{2}{*}{$\begin{array}{l}\text { Mean } \\
\text { difference }^{a}(I-J)\end{array}$} & \multirow{2}{*}{$\begin{array}{l}\text { Std. } \\
\text { error }\end{array}$} & \multirow[t]{2}{*}{ Sig. } & \multicolumn{2}{|c|}{ 95\% confidence interval } \\
\hline & & & & & & $\begin{array}{l}\text { Lower } \\
\text { bound }\end{array}$ & $\begin{array}{l}\text { Upper } \\
\text { bound }\end{array}$ \\
\hline \multirow{6}{*}{$\begin{array}{l}\text { Perceived } \\
\text { quality }\end{array}$} & \multirow[t]{2}{*}{ 20-35 years } & $36-50$ years & $-7.34524^{*}$ & 1.33048 & .000 & -10.4796 & -4.2109 \\
\hline & & $\begin{array}{l}\text { Above } 50 \\
\text { years }\end{array}$ & $22.23810^{*}$ & 1.00930 & .000 & 19.8537 & 24.6225 \\
\hline & \multirow[t]{2}{*}{$36-50$ years } & 20-35 years & $7.34524^{*}$ & 1.33048 & .000 & 4.2109 & 10.4796 \\
\hline & & $\begin{array}{l}\text { Above } 50 \\
\text { years }\end{array}$ & $29.58333^{*}$ & .86689 & .000 & 27.5229 & 31.6437 \\
\hline & \multirow{2}{*}{$\begin{array}{ll}\text { Above } 50 \\
\text { years }\end{array}$} & 20-35 years & $-22.23810^{*}$ & 1.00930 & .000 & -24.6225 & -19.8537 \\
\hline & & $36-50$ years & $-29.58333^{*}$ & .86689 & .000 & -31.6437 & -27.5229 \\
\hline \multirow[t]{6}{*}{ Brand loyalty } & \multirow[t]{2}{*}{$20-35$ years } & $36-50$ years & $-4.46429^{*}$ & .76400 & .000 & -6.2642 & -2.6644 \\
\hline & & $\begin{array}{l}\text { Above } 50 \\
\text { years }\end{array}$ & $18.61905^{*}$ & .57094 & .000 & 17.2702 & 19.9679 \\
\hline & \multirow[t]{2}{*}{ 36-50 Year } & 20-35 years & $4.46429^{*}$ & .76400 & .000 & 2.6644 & 6.2642 \\
\hline & & $\begin{array}{l}\text { Above } 50 \\
\text { years }\end{array}$ & $23.08333^{*}$ & .50766 & .000 & 21.8767 & 24.2899 \\
\hline & \multirow{2}{*}{$\begin{array}{l}\text { Above } \\
\text { years }\end{array}$} & 20-35 years & $-18.61905^{*}$ & .57094 & .000 & -19.9679 & -17.2702 \\
\hline & & $36-50$ years & $-23.08333^{*}$ & .50766 & .000 & -24.2899 & -21.8767 \\
\hline \multirow[t]{6}{*}{ Brand image } & \multirow[t]{2}{*}{ 20-35 years } & $36-50$ years & $-2.58333^{*}$ & .62764 & .000 & -4.0636 & -1.1031 \\
\hline & & $\begin{array}{l}\text { Above } 50 \\
\text { years }\end{array}$ & $3.00000^{*}$ & .39947 & .000 & 2.0563 & 3.9437 \\
\hline & \multirow[t]{2}{*}{$36-50$ years } & 20-35 years & $2.58333^{*}$ & 62764 & .000 & 1.1031 & 4.0636 \\
\hline & & $\begin{array}{l}\text { Above } 50 \\
\text { years }\end{array}$ & $5.58333^{*}$ & .48411 & .000 & 4.4327 & 6.7339 \\
\hline & \multirow{2}{*}{$\begin{array}{l}\text { Above } \\
\text { years }\end{array}$} & 20-35 years & $-3.00000^{*}$ & .39947 & .000 & -3.9437 & -2.0563 \\
\hline & & $36-50$ years & $-5.58333^{*}$ & .48411 & .000 & -6.7339 & -4.4327 \\
\hline \multirow[t]{6}{*}{ Brand awareness } & \multirow[t]{2}{*}{ 20-35 years } & $36-50$ years & $-1.29762^{*}$ & .44820 & .011 & -2.3534 & -.2418 \\
\hline & & $\begin{array}{l}\text { Above } 50 \\
\text { years }\end{array}$ & $3.61905^{*}$ & .35192 & .000 & 2.7877 & 4.4504 \\
\hline & \multirow[t]{2}{*}{$36-50$ years } & 20-35 years & $1.29762^{*}$ & .44820 & .011 & .2418 & 2.3534 \\
\hline & & $\begin{array}{ll}\text { Above } 50 \\
\text { years }\end{array}$ & $4.91667^{*}$ & .27756 & .000 & 4.2570 & 5.5764 \\
\hline & \multirow{2}{*}{$\begin{array}{l}\text { Above } 50 \\
\text { years }\end{array}$} & 20-35 years & $-3.61905^{*}$ & .35192 & .000 & -4.4504 & -2.7877 \\
\hline & & $36-50$ years & $-4.91667^{*}$ & .27756 & .000 & -5.5764 & -4.2570 \\
\hline \multirow{6}{*}{$\begin{array}{l}\text { Purchase } \\
\text { behavior }\end{array}$} & \multirow[t]{2}{*}{$20-35$ years } & $36-50$ years & $-1.63095^{*}$ & .29779 & .000 & -2.3325 & -.9294 \\
\hline & & $\begin{array}{l}\text { Above } 50 \\
\text { years }\end{array}$ & $5.61905^{*}$ & .25212 & .000 & 5.0234 & 6.2147 \\
\hline & \multirow[t]{2}{*}{$36-50$ years } & 20-35 years & $1.63095^{*}$ & .29779 & .000 & .9294 & 2.3325 \\
\hline & & $\begin{array}{ll}\text { Above } 50 \\
\text { years }\end{array}$ & $7.25000^{*}$ & .15848 & .000 & 6.8733 & 7.6267 \\
\hline & \multirow{2}{*}{$\begin{array}{ll}\text { Above } 50 \\
\text { years }\end{array}$} & $20-35$ years & $-5.61905^{*}$ & .25212 & .000 & -6.2147 & -5.0234 \\
\hline & & $36-50$ years & $-7.25000^{*}$ & .15848 & .000 & -7.6267 & -6.8733 \\
\hline $\begin{array}{l}\text { *. The mean diffe } \\
{ }^{a} \text {-Mean Differenc }\end{array}$ & ence is signif & $\begin{array}{l}\text { ant at the } 0.0 \\
\text { a }<\mathrm{J} \\
\text { hean } \mathrm{I}>\mathrm{J}\end{array}$ & level. & & & & \\
\hline
\end{tabular}


Table 5. Significant results in a post-hoc analysis after a significant result from One Way ANOVA test between all variables and income level

\begin{tabular}{|c|c|c|c|c|c|c|c|}
\hline \multicolumn{8}{|c|}{ Multiple comparisons } \\
\hline \multirow{2}{*}{$\begin{array}{l}\text { Dependent } \\
\text { variable }\end{array}$} & \multirow[t]{2}{*}{$\mathbf{I}$} & \multirow[t]{2}{*}{$\mathbf{J}$} & \multirow{2}{*}{$\begin{array}{l}\text { Mean difference }{ }^{\mathrm{a}} \\
\text { (I-J) }\end{array}$} & \multirow{2}{*}{$\begin{array}{l}\text { Std. } \\
\text { error }\end{array}$} & \multirow[t]{2}{*}{ Sig. } & \multicolumn{2}{|c|}{$95 \%$ confidence interval } \\
\hline & & & & & & $\begin{array}{l}\text { Lower } \\
\text { bound }\end{array}$ & $\begin{array}{l}\text { Upper } \\
\text { bound }\end{array}$ \\
\hline \multirow{6}{*}{$\begin{array}{l}\text { Perceived } \\
\text { quality }\end{array}$} & \multirow[t]{3}{*}{ Below 5000} & $5001-10000$ & -3.83333 & 1.54587 & .066 & -7.8392 & .1725 \\
\hline & & $10001-15000$ & $-10.00000^{*}$ & 1.23763 & .000 & -13.2150 & -6.7850 \\
\hline & & Above 15000 & $-7.50000^{*}$ & 1.75004 & .000 & -12.0297 & -2.9703 \\
\hline & \multirow[t]{3}{*}{$10001-15000$} & Below 5000 & $10.00000^{*}$ & 1.23763 & .000 & 6.7850 & 13.2150 \\
\hline & & $5001-10000$ & $6.16667^{*}$ & .92626 & .000 & 3.7098 & 8.6235 \\
\hline & & Above 15000 & 2.50000 & 1.23729 & .188 & -.7395 & 5.7395 \\
\hline \multirow{6}{*}{$\begin{array}{l}\text { Brand } \\
\text { loyalty }\end{array}$} & \multirow[t]{3}{*}{ Below 5000} & $5001-10000$ & $-3.96078^{*}$ & .92364 & .000 & -6.3558 & -1.5657 \\
\hline & & $10001-15000$ & -1.29412 & .70479 & .260 & -3.1249 & .5367 \\
\hline & & Above 15000 & $-4.09412^{*}$ & 1.10040 & .001 & -6.9451 & -1.2432 \\
\hline & \multirow[t]{3}{*}{$10001-15000$} & Below 5000 & 1.29412 & .70479 & .260 & -.5367 & 3.1249 \\
\hline & & $5001-10000$ & $-2.66667^{*}$ & .59699 & .000 & -4.2501 & -1.0832 \\
\hline & & Above 15000 & $-2.80000^{*}$ & .84508 & .007 & -5.0126 & -.5874 \\
\hline \multirow{6}{*}{$\begin{array}{l}\text { Brand } \\
\text { image }\end{array}$} & \multirow[t]{3}{*}{ Below 5000} & $5001-10000$ & -.98039 & .90858 & .703 & -3.3578 & 1.3970 \\
\hline & & $10001-15000$ & $-1.64706^{*}$ & .45962 & .003 & -2.8410 & -.4531 \\
\hline & & Above 15000 & $-4.24706^{*}$ & .60746 & .000 & -5.8187 & -2.6754 \\
\hline & \multirow{3}{*}{$\begin{array}{l}\text { Above } \\
15000\end{array}$} & Below 5000 & $4.24706^{*}$ & .60746 & .000 & 2.6754 & 5.8187 \\
\hline & & $5001-10000$ & $3.26667^{*}$ & .87864 & .002 & .9616 & 5.5718 \\
\hline & & $10001-15000$ & $2.60000^{*}$ & .39718 & .000 & 1.5601 & 3.6399 \\
\hline \multirow{6}{*}{$\begin{array}{l}\text { Brand } \\
\text { awareness }\end{array}$} & \multirow[t]{3}{*}{ Below 5000} & $5001-10000$ & -1.21569 & .62733 & .217 & -2.8461 & .4147 \\
\hline & & $10001-15000$ & .11765 & .42638 & .993 & -.9899 & 1.2252 \\
\hline & & Above 15000 & $-2.18235^{*}$ & .48564 & .000 & -3.4395 & -.9252 \\
\hline & \multirow[t]{3}{*}{$10001-15000$} & Below 5000 & -.11765 & .42638 & .993 & -1.2252 & .9899 \\
\hline & & $5001-10000$ & $-1.33333^{*}$ & .46015 & .027 & -2.5539 & -.1128 \\
\hline & & Above 15000 & $-2.30000^{*}$ & .23248 & .000 & -2.9087 & -1.6913 \\
\hline \multirow{3}{*}{$\begin{array}{l}\text { Purchase } \\
\text { behavior }\end{array}$} & \multirow{3}{*}{$\begin{array}{l}\text { Above } \\
15000\end{array}$} & Below 5000 & $1.35294^{*}$ & .40320 & .005 & .3098 & 2.3961 \\
\hline & & $5001-10000$ & $1.50000^{*}$ & .36746 & .000 & .5439 & 2.4561 \\
\hline & & $10001-15000$ & $1.00000^{*}$ & .25965 & .001 & .3202 & 1.6798 \\
\hline \multicolumn{8}{|c|}{ *. The mean difference is significant at the 0.05 level. } \\
\hline \multicolumn{8}{|c|}{${ }^{\mathrm{a}}$-Mean Difference $(-)$ value $=$ mean $\mathrm{I}<\mathrm{J}$} \\
\hline \multicolumn{8}{|c|}{ Mean Difference $(+)$ value $=$ mean $\mathrm{I}>\mathrm{J}$} \\
\hline
\end{tabular}


Table 6. Significant results in a post-hoc analysis after a significant result from One Way ANOVA test between all variables and educational level

\begin{tabular}{|c|c|c|c|c|c|c|c|}
\hline \multicolumn{8}{|c|}{ Multiple comparisons } \\
\hline \multirow[t]{2}{*}{$\begin{array}{l}\text { Dependent } \\
\text { variable }\end{array}$} & \multirow[t]{2}{*}{$\mathbf{I}$} & \multirow[t]{2}{*}{$\mathbf{J}$} & \multirow[t]{2}{*}{$\begin{array}{l}\text { Mean difference }{ }^{\mathrm{a}} \\
(\mathrm{I}-\mathrm{J})\end{array}$} & \multirow[t]{2}{*}{$\begin{array}{l}\text { Std. } \\
\text { error }\end{array}$} & \multirow[t]{2}{*}{ Sig. } & $\begin{array}{l}95 \% \\
\text { interval }\end{array}$ & confidence \\
\hline & & & & & & $\begin{array}{l}\text { Lower } \\
\text { bound }\end{array}$ & $\begin{array}{l}\text { Upper } \\
\text { bound }\end{array}$ \\
\hline \multirow[t]{2}{*}{ Brand image } & \multirow[t]{2}{*}{ Postgraduate } & Matriculate & $2.93939^{*}$ & .90226 & .001 & 1.1639 & 4.7149 \\
\hline & & Graduate & $1.86096^{*}$ & .68792 & .007 & .5073 & 3.2147 \\
\hline \multirow[t]{2}{*}{ Brand awareness } & \multirow[t]{2}{*}{ Graduate } & Matriculate & $-2.38235^{*}$ & .81089 & .012 & -4.3192 & -.4455 \\
\hline & & Postgraduate & $-1.33690^{*}$ & .46287 & .012 & -2.4283 & -.2455 \\
\hline \multicolumn{8}{|c|}{ *. The mean difference is significant at the 0.05 level. } \\
\hline \multicolumn{8}{|c|}{${ }^{\mathrm{a}}$-Mean Difference $(-)$ value $=$ mean $\mathrm{I}<\mathrm{J}$} \\
\hline \multicolumn{8}{|c|}{ Mean Difference $(+)$ value $=$ mean $\mathrm{I}>\mathrm{J}$} \\
\hline
\end{tabular}

\section{Gender}

Gender is significant to the five study variables. The males scored significantly higher in all domains (perceived quality, p-value 0.002 ; brand loyalty, p-value $<0.001$; brand image, $\mathrm{p}$-value $<0.001$; brand awareness, $\mathrm{p}$-value $<0.001$ and purchase behavior, $\mathrm{p}$-value $<0.001$ ).

\section{Nationality}

Nationality is only significant in the domain purchase behavior. Saudis in this domain scored significantly higher compared to non-Saudis, p-value $<0.001$.

Age

The different age brackets of the samples scored significantly differently in all the domains. Under all the domains, samples aged 20 to 35 years old scored significantly lower compared to samples aged 36 to 50 years old, and significantly higher compared to samples aged above 50 years old. Respondents aged 36 to 50 years old scored significantly higher compared to those who are aged 20 to 35 and above 50 years old. Lastly, samples that are above 50 years old scored significantly lower compared to samples of 20 to 35 and 36 to 50 years old.

\section{Monthly Income}

The samples with different income brackets scored significantly differently under all study variables. In the domains perceived quality and brand image, samples with income of below 5000 scored significantly lower than the samples with income that ranges from 10001 to 15000 and those with income above 15000 . Samples with income that ranges from 10001 to 15000 scored significantly higher than those with income below 5000, from 5001 to 10000 and above 15000 .

Under the domain brand loyalty, samples with monthly income of below 5000 scored significantly lower compared to those whose incomes are from 5001 to 10000 and above 15000. Samples with monthly income ranging from 10001 to 15000 scored significantly lower compared to those whose income is from 5001 to 10000 and above 15000 .

In the domain brand awareness, samples with monthly income of below 5000 scored significantly lower compared to those whose income is from 5001 to 10000 and above 15000. Samples whose income is from 10001 to 15000 scored significantly lower compared to those whose income is from 5001 to 10000 and above 15000 .

Lastly, under the domain purchase behavior, those samples whose income is above 15000 scored significantly higher compared to those whose income is below 5000, from 5001 to 10000 and from 10001 to 15000.

\section{Level of Education}

As to the variable educational attainment, samples who have postgraduate levels scored significantly higher compared to those who are matriculate and graduates in the domain brand image, while in the domain brand awareness, the samples who graduated scored significantly lower compared to those who are matriculate and had postgraduate levels. 
Table 7. Correlation between the independent and dependent variables

\begin{tabular}{|c|c|c|}
\hline \multicolumn{3}{|c|}{ Correlations } \\
\hline \multicolumn{2}{|c|}{ Domains } & Purchase behavior \\
\hline \multirow[t]{3}{*}{ Perceived quality } & $\mathrm{R}$ & $.789^{* *}$ \\
\hline & $\mathrm{p}$-value & .000 \\
\hline & $\mathrm{N}$ & 306 \\
\hline \multirow[t]{3}{*}{ Brand loyalty } & $\mathrm{R}$ & $.819^{* *}$ \\
\hline & $\mathrm{p}$-value & .000 \\
\hline & $\mathrm{N}$ & 306 \\
\hline \multirow[t]{3}{*}{ Brand image } & $\mathrm{r}$ & $.625^{* *}$ \\
\hline & $\mathrm{p}$-value & .000 \\
\hline & $\mathrm{N}$ & 306 \\
\hline \multirow[t]{3}{*}{ Brand awareness } & $\mathrm{r}$ & $.763^{* *}$ \\
\hline & $\mathrm{p}$-value & .000 \\
\hline & $\mathrm{N}$ & 306 \\
\hline
\end{tabular}

**. Correlation is significant at the 0.01 level (2-tailed).

If $r=+.70$ or higher Very strong positive relationship

+.40 to +.69 Strong positive relationship

+.30 to +.39 Moderate positive relationship

+.20 to +.29 Weak positive relationship

+.01 to +.19 No or negligible relationship

-.01 to -.19 No or negligible relationship

-.20 to -.29 Weak negative relationship

-.30 to -.39 Moderate negative relationship

-.40 to -.69 Strong negative relationship

-.70 or higher Very strong negative relationship

As the four domains increase, the purchasing behavior also positively increases significantly using Pearson's Correlation Coefficient.

Table 8. General linear model using univariate regression test

\begin{tabular}{|c|c|c|c|c|c|c|}
\hline \multicolumn{7}{|c|}{ Tests of between-subjects effects } \\
\hline \multicolumn{7}{|c|}{ Dependent variable: Purchase behavior } \\
\hline Source & Type III Sum of squares & Df & Mean square & $\mathbf{F}$ & p-value & Partial Eta squared \\
\hline Corrected model & $2547.603^{\mathrm{a}}$ & 12 & 212.300 & 119.363 & $<0.001$ & .830 \\
\hline Intercept & 37.671 & 1 & 37.671 & 21.180 & $<0.001$ & .067 \\
\hline Gender & 28.281 & 1 & 28.281 & 15.901 & $<0.001$ & .051 \\
\hline Nationality & 165.264 & 1 & 165.264 & 92.918 & $<0.001$ & .241 \\
\hline Age & 8.413 & 2 & 4.206 & 2.365 & .096 & .016 \\
\hline Monthly income & 21.988 & 3 & 7.329 & 4.121 & .007 & .040 \\
\hline Perceived quality & 85.643 & 1 & 85.643 & 48.152 & $<0.001$ & .141 \\
\hline Brand loyalty & 66.868 & 1 & 66.868 & 37.596 & $<0.001$ & .114 \\
\hline Brand image & 20.558 & 1 & 20.558 & 11.558 & .001 & .038 \\
\hline Brand awareness & 42.022 & 1 & 42.022 & 23.626 & $<0.001$ & .075 \\
\hline Error & 521.132 & 293 & 1.779 & & & \\
\hline Total & 47349.000 & 306 & & & & \\
\hline Corrected total & 3068.735 & 305 & & & & \\
\hline
\end{tabular}


Table 9. Significant results sorted from highest to lowest based on the level of contribution relative to the variability of purchasing behavior

\subsection{Statistical Tests}

\begin{tabular}{ll}
\hline Predictors & Partial Eta Squared \\
\hline Nationality & 0.241 \\
\hline Perceived quality & 0.141 \\
\hline Brand loyalty & 0.114 \\
\hline Brand awareness & 0.075 \\
\hline Gender & 0.051 \\
\hline Monthly income & 0.04 \\
\hline Brand image & 0.038 \\
\hline Age & 0.016 \\
\hline
\end{tabular}

In this study, the variables with categorical values and numbers are represented by mean, range and variations, using simple descriptive statistics. Furthermore, the additive method scored five domains. These domains are compared to the characteristics of the study variables (sections A and B in the questionnaire) using independent $t$-test and One-Way ANOVA for variables with two groups and three or more groups. Normality is assumed using Levene's test for Homogeneity of Variance. In case of unequal variance, a Welch $t$-test was used as an alternative to independent $t$-test and post-hoc analysis LSD (least significant difference), and Games-Howell was used, given that significant results came up using a One-Way ANOVA test. A Pearson's correlation coefficient was used to check the dependency of the domains to purchasing behavior. Lastly, a general linear model using a univariate regression test was used to quantify each significant predictor relative to their contribution to the variability of dependent variable that is the purchasing behavior. A p-value $<0.05$ was a criteria to reject the null hypothesis. Every test was analyzed using IBM SPSS v22.

\subsection{Conclusion of Statistical Analysis}

Regarding characteristics of the study variables, nationality was the most positive influencing variable on purchasing behavior. Saudis have higher purchase behavior. Next, the impact of perceived quality: the higher the perception of the quality, the higher the purchasing behavior. Third is brand loyalty: greater frequency or patronage of a certain brand or service leads to higher purchasing behavior. Then, brand awareness: the more they are familiarized with a certain brand of services provided, the higher the purchase behavior will be. Fifth is gender, wherein males have higher purchase behavior than females. Next is monthly income followed by brand image, then age. It must be noticed that characteristics of the study variables section B was weak, and has no significance on purchasing behavior, so it is neglected.

\section{Research Discussion}

This part of the study aims to discuss the findings and results that have emerged from the data analysis presented in the research analysis. In addition, comparisons have been drawn with other related studies in literature. Empirically, the model assumed that brand equity components have an impact on patients' purchasing behavior. It additionally predicted that the impact of such components on patients' purchasing behavior is linked with nationality, which was found to be the demographic with the most effect on purchasing behavior. Three hundred and six patients from different private hospitals in Jeddah city were included in this research. The research sample consists of males and females, with the number of males approximately double the number of females. Analysis shows that brand awareness influences patients' purchasing behavior, a result which is consistent with the Aluregowda (2013) study, which found that brand awareness was needed to distribute information on the meaning of the brand, to attract customers, and to build strong brand position and presence. In the same vein, the study is also consistent with a study by Karbalaei et al. (2013), which found that brand awareness is linked to patient satisfaction and trust, which then leads to strong relations between brand awareness and purchasing behavior, as the patient requires trust and satisfaction before paying. The brand image in this study was significant. The researcher found that there is a significant relationship between brand image and patients' purchasing behavior. The results are supported by Solayappan and Jayakrishnan (2010), who found that brand image provides a clear insight into the customer's relationship with the brand. However, Chahal and Bala (2010) found that brand image has an indirect effect on service brand equity. Brand loyalty in this study was significant. However, Chahal and Bala (2010) agreed with the 
significance of brand loyalty as a major component of brand equity. They linked brand loyalty with positive attitude (attitudinal loyalty) and repeat purchase behavior (behavioral loyalty) of consumers toward the hospital. Wu (2011) agreed with this research in brand loyalty as a significant positive influence on hospital brand image, improving patient satisfaction through enhancing the perception of service quality, which in turn increases the re-visit intention of patients. Malik et al. (2012) focus on how significant is the relation between (brand knowledge, brand social responsibility image, service involvement and perceived service quality) and brand loyalty. And this confirms the strong relation between these dimensions together. Moreover, not far away, Karbalaei et al. (2013) found that brand loyalty was affected by trust, satisfaction and relationship commitment, while it enhances the hospital image overall. Again, by using logic and reason, it is possible to conclude that brand loyalty is an important component of brand equity and has an important role in the purchasing behavior of the patient. Finally, perceived quality was significant in this study, as agreed by Chahal and Bala (2010), who found that perceived quality has an influence on brand equity as a component. Malik et al. (2012) focused on the significant relation between perceived quality and brand loyalty. Moreover, it can be concluded from that study that the presumptive order of the components of brand equity are perceived quality, brand loyalty, brand awareness and brand image. For example, this order can be observed when a patient has a positive experience in a dental clinic (perceived quality), and this will encourage him to come again and recommend the clinic to others (brand loyalty); then he will start informing about the clinic around him (brand awareness), and then an imaginary image will be created in his mind (brand image). The result of this series will positively affect the purchasing behavior.

\section{Research Conclusion}

The study focuses on a framework of dental services' brand equity components, namely brand loyalty, brand image, brand awareness, and perceived quality influencing patients' purchasing behavior. Specifically, the study indicates that nationality is the only demographic variable to have an effect on purchasing behavior. In addition, the brand equity components have a positive influence on purchasing behavior in dental services. Moreover, this supports the research hypothesis and rejects the null hypothesis. The service provider, when implementing these items, positively contributes to brand loyalty, brand image, brand awareness, and perceived quality. The study findings reveal certain significant outcomes relating to brand equity components. First, strengthen perceived quality; patients indicate that dental practices management should focus on staff behavior, assurance, and tangibility. In a more specific context, important characteristics of staff behavior contributing to perceived quality were considered as communication quality, prescription quality, rapid response to queries, and caring attitude of the staff. Whereas assurance quality focused on a feeling of safety in the patients' mind, the responsive quality and supportive attitude of the staff contributing to perceived quality. Finally, tangible factor items such as availability of state-of-the-art technology equipment and availability of a parking facility, add to perceived service quality. Overall results underscore that perceived service quality helps to speed recovery of patients and improve their health, through an effective dental service delivery process. Moreover, delivering qualitative customized services can build trust and positive feelings in patients towards the dental clinic, which subsequently enhance purchasing behavior. Perceived quality results in superior performance and a sustainable competitive advantage for a dental clinic. Second is brand loyalty, which is linked with indicators associated with attitudinal loyalty and behavioral loyalty (i.e. consequences of patient satisfaction). High and positive patients' perception towards brand loyalty are pointed out as the preference of patients to use the same or different medical treatments from the same dental practice in future as well. Such patients share positive experiences about the dental services with their friends and relatives, and recommend the clinic to them. Later, this helps in building a positive dental practice image in the minds of the users and potential users. Third is brand awareness, which is linked with familiarity, brand recall and brand recognition. Besides that, the patients need to notice the improvement in the brand's performance. All of that will affect the patients before purchasing. Regarding the last component of service brand equity, the study concludes that the predictive power of brand image is also significant in influencing purchasing behavior. The dental clinic has a good social activity with their patients. In the same vein, the dental clinic is quiet and restful. Overall, the study concludes that perceived quality, brand loyalty, brand awareness, and brand image have an influence on the purchasing behavior of dental services in the healthcare sector. More importantly, organizations with a high degree of service brand equity will be efficient in sustaining a competitive situation.

\section{Research Recommendations}

The dental service provider should concentrate on perceived quality by improving their technical equipment, selecting their staff from experts and frontline employees, providing qualified dental services represented by perfect behavior, in a decent-looking and comfortable environment. The dental service provider must know that brand loyalty is how they are seen as winning among their competitors. The dental service provider should focus on enhancing their brand awareness and brand image using their patients themselves, as well as all media channels to reach more patients' hearts 
and minds. The dental services provider should pay more attention to strategic planning, and building and maintaining their brand equity, in order to retain their existing patients and generate new ones.

\section{Limitations and Avenues for Future Research}

While this research has given valuable insight, there are some limitations which may limit generalizability:

Limited studies have been applied in the domain of healthcare, and especially dentistry. Some difficulties met the distribution of the research questionnaire, because of the scattered nature of the dental practices in different locations in Jeddah city. Some dental respondents refused to take part in the questionnaire. This research took place only in one health service industry, dental practices, which might imply that the generalizability of the research results is limited to the general private sector hospitals in Jeddah city.

During the conduct of this research, a number of ideas for further research and future study came to light, which were:

applying the study to other health service sectors, e.g. public sector ( $\mathrm{MOH}$ hospitals or Armed Forces Hospitals) in order to develop a model that represents the health service sector more generally; applying the same study using a comparative method between dental services and private hospitals in general.

\section{References}

Al-Dmour, H., Al-Zu'bi, Z.M. \& Kakee, D. (2013). The Effect of Services Marketing Mix Elements on Customer-Based Brand Equity: An Empirical Study on Mobile Telecom Service Recipients in Jordan. International Journal of Business and Management, 8(11). http://dx.doi.org/10.5539/ijbm.v8n11p13

Aluregowda. (2013). Role Of Brand Awareness In Health Care Industry. International Monthly Refereed Journal of Research In Management \& Technology, II.

Brosekhan, A.A, Velayutham, C.M. (n.d.). Consumer Buying Behaviors - A Literature Review. IOSR Journal of Business and Management, 8-16.

Chahal, H. \& Bala, M. (2012). Significant components of service brand equity in healthcare sector. International Journal of Health Care Quality Assurance, 343-362. http://dx.doi.org/10.1108/09526861211221518

Chao-Chan, W. (2011). The impact of hospital brand image on service quality,patient satisfaction and loyalty. African Journal of Business Management, 5(12), 4873-4882.

Chi, H.K., Yeh, H.R., Chien, S. \& Yang, Y.T. (2009). The Impact of Brand Awareness on Consumer Purchase Intention: The Mediating Effect of Perceived Quality and Brand Loyalty. The Journal of International Management Studies, 4(1).

Chi, H.S., Yeh, H.R. \& Yang, Y.T. (2009). The Impact of Brand Awareness on Consumer Purchase Intention: The Mediating Effect of Perceived Quality and Brand Loyalty. The Journal of International Management Studies, $4(1)$.

Chieng, F.Y.-L. \& Goi, C.-L. (2011). Customer-based brand equity: A study on interrelationship among the brand equity dimension in Malaysia. African Journal of Business Management, 5, 11856-11862.

Corbina, C.L., Kelley, S.W. and Schwartz, R.W. (2001). Concepts in service marketing for healthcare professionals. The American Journal of Surgery, pp.1-7. http://dx.doi.org/10.1016/S0002-9610(00)00535-3

Creswell, J. (2003). Research Design - Qualitative, Quantitative and Mixed Methods and Approaches, Second Edition. Thousand Oaks, Calif, Sage Publication.

Duggirala, M., Rajendran, C. \& Anantharaman, R. (2008). Patient-perceived dimensions of total quality service in healthcare. Benchmarking: an International Journal, 15(5), 560-583.

Esquire, N.A., Al-Ammar, M.I. \& Mostafa, S. (2009). Healthcare and Pharmaceutical Industries in Saudi Arabia, Dubai and Riyadh: International healthcare affinity group of the business law and governance practice group.

Irshad, W. (2012). Service Based Brand Equity, Measure of Purchase Intention, and Mediating Role of Brand Performance. Academy of Contemporary Research Journal, 1(I), 1-10.

Jalilvand, M.R., Samiei, N. \& Mahdavinia, S.H. (2011). The Effect of Brand Equity Components on Purchase Intention: An Application of Aaker's Model in the Automobile Industry. International Business and Management, 2(2), 149-158. 
Karbalaei, M., Abd, A., Malmir, R., Dehghanan, H., Pirnejad, S. \& Jaf, S. (2013). Investigating of Brand Equity on Hospital Image. Research Journal of Applied Sciences, Engineering and Technology, 3388-3394.

Kim, K., Kim, K., Kim, D., Kim, J. \& Kang, S. (2008). Brand equity in hospital marketing. Journal of Business Research. http://dx.doi.org/10.1016/j.jbusres.2006.05.010

Kotler, P., Shalowitz, J. \& Stevens, R.J. (2008). Strategic marketing for health care organizations: building a customer-driven health system. San Francisco: John Wiley and Sons, Inc.

Kumar, N., Jacob, A. \& Thota, S. (2014). Impact of Healthcare Marketing and Branding on Hospital Services. International Journal of Research Foundation of Hospital \& Healthcare Adminstration, 19-24. http://dx.doi.org/10.5005/jp-journals-10035-1010

Lee, G.C. (2011). Customer-based brand equity: a literature review. Journal of Arts Science \&Commerce, I.

Malik, M.E., Naeem, B. \& Mun, M. (2012). Brand Image: Past, Present and Future. Journal of Basic and Applied Scientific Research, 13069-13075.

Palmer, A. (2001). Principles of Services Marketing, UK: Third Edition. McGraw-Hill Publishing Company.

Solayappan, A. \& Jayakrishnan, J. (2010). Key Determinants of Brand-Customer Relationship in Hospital Industry. Economic Sciences Series, 119-128.

Sun, J.B. (2004). Brand Equity, Perceived Value And Revisit Intention In The US Mid-Priced Hotel Segment. USA: Oklahoma State University.

Wood, L. (2000). Brands and brand equity: definition and management. Management Decision, 662-669. http://dx.doi.org/10.1108/00251740010379100

$\mathrm{Wu}$, C.C. (2011). The impact of hospital brand image on service quality, patient satisfaction and loyalty. African Journal of Business Management, 5(12), 4873-4882. 